\title{
Performance Improvement of Roof Transparent Solar Still Coupled With Agriculture Greenhouse
}

\author{
Alaa H. Salah ${ }^{1}$ Gasser E. Hassan ${ }^{2}$ Mohamed Elhelw ${ }^{3}$ Hassan Fath $^{4}$, Samy M. Elsherbiny ${ }^{5}$ \\ ${ }^{(1,2)}$ Department of Computer-Based Engineering Applications, City for Scientific Research and Technological \\ Applications, Alexandria, Egypt \\ ${ }^{(3,4,5)}$ Mechanical Engineering Department ,Faculty of Engineering, Alexandria University, Alexandria, Egypt \\ 1alaasalah4@yahoo.com
}

\begin{abstract}
In Egyptian desert, growing plants is difficult due to harsh climate (hot at the daytime and cold at the night), infertile soil, low average rainfall and lack of fresh water for irrigation purposes. A set of simple transparent solar stills are integrated with a new solar driven agriculture greenhouse $(\mathrm{GH})$. The stills are placed at the $\mathrm{GH}$ roof to use the extra solar radiation (above that required for plant photosynthesis process) for water desalination. In addition to water desalination concept the solar still units even reduce the cooling load during the daytime. A net of aluminum metal coated with black colour is placed on the base of the solar still units to raise the water temperature (enhance desalination process) and provide partially shading for the $\mathrm{GH}$. Using aluminum net decreases also the number of solar still units required to produce the required amount of $\mathrm{GH}$ fresh water leading to a significant cost reduction.. Therefore, this technique can be used for the application where a higher VTR is essential.
\end{abstract}

The main objectives of this work are sizing of the aluminum net, spacing between solar still units to obtain the threshold of plant requirements. Also fresh water production and greenhouse climatic conditions that plant needs (temperature, relative humidity, air velocity and amount of oxygen) are simulated.

Numerical simulation was carried out for the hottest day of Borg Elarab, Alexandria (Egypt).
Keywords - renewable energy; solar energy; water desalination; agriculture greenhouse; solar stills

\section{INTRODUCTION}

Water, suitable soil, solar radiation and suitable climate are the major parameters for high quality and quantity plants production. Most of Egypt deserts are not used because of water shortage and harsh climatic conditions.

The threshold of solar radiation plant needs for photosynthesis process is $8.46 \mathrm{MJ} / \mathrm{m} 2$.day (2.35 $\mathrm{kW} . \mathrm{hr} / \mathrm{m} 2$.day) [1]. Plants often need a temperature in the range of $10-30 \mathrm{oC}$ and a relative humidity in the range of $60-90 \%$ [2]. Where the temperature should not be high to avoid water stress resulting from water losses through the plant leaves. Also, low humidity increases the water loss as a result of transpiration. On the other hand high humidity severely limits evaporation rates, so water is not being transported from the root zone and neither are any nutrients [3]. Therefore, solar radiation, temperature and relative humidity should be controlled to produce a proper environment for plant growth. GH can present an agriculture solution as the main environmental factors can be controlled as temperature, relative humidity, and photosynthetic photon flux. 


\begin{tabular}{|c|c|}
\hline Parameter & Nomenclature \\
\hline$A_{g r}$ & Area of the greenhouse floor \\
\hline$B_{c}$ & Breadth of the channel \\
\hline$C_{p, g}$ & Specific heat of glass \\
\hline$C_{p, p}$ & Specific heat of the plants \\
\hline$C_{p, a l}$ & Specific heat of aluminum \\
\hline$H_{b}$ & Heat transfer coefficient to soil \\
\hline$h_{w}$ & Height of water in the solar still \\
\hline L & Length of the $\mathrm{GH}$ \\
\hline LAI & Leaf area index \\
\hline$L_{b}$ & Base length of solar still \\
\hline $\mathrm{Ip}$ & Characteristic length of a leaf \\
\hline$M_{p}$ & Mass of the plants \\
\hline$m_{\text {air }}$ & Mass flow rate of mixed air \\
\hline$N_{S S, r}$ & No. of solar still units in vertical riser \\
\hline$N_{S S, h}$ & No. of solar still units in horizontal riser \\
\hline $\mathrm{ra}$ & Plant aerodynamic resistance \\
\hline rs & Plant stomatal resistance \\
\hline Tco & Cooling water temperature \\
\hline$T_{o}$ & Temperature of soil at larger depth \\
\hline$t_{n e t}$ & The thickness of the metal net \\
\hline$W$ & Width of the GH into paper \\
\hline$\alpha_{a l}$ & Absorptivity of aluminum \\
\hline$\alpha_{p}$ & Absorptivity of the plants \\
\hline$\alpha_{g}$ & Absorptivity of glass \\
\hline$\alpha_{g r}$ & Absorptivity of the GH floor \\
\hline$\alpha_{w}$ & Absorptivity of water \\
\hline$\square$ & Angle of the solar still cover \\
\hline$\varepsilon_{g}$ & Emissivity of glass \\
\hline$\varepsilon_{g r}$ & Emissivity of the GH floor \\
\hline$\varepsilon_{p}$ & Emissivity of the plants \\
\hline$\varepsilon_{w}$ & Emissivity of water \\
\hline$\rho_{A l}$ & Density of aluminum \\
\hline$\rho_{g}$ & Density of glass \\
\hline$\rho_{w}$ & Density of water \\
\hline$\tau_{g}$ & Transmissivity of glass \\
\hline$\tau_{w}$ & Transmissivity of water \\
\hline$\Delta$ Tapp & Approach temperature \\
\hline
\end{tabular}

A new GH design of inside controlled climate, solar driven and self-sufficient of water production agriculture greenhouse system is developed to overcome these problems [2-4] where a roof solar stills are placed on the $\mathrm{GH}$ roof.

In this paper, a net of aluminum coated by black color is placed over the base of solar still units to enhance the desalination process. A mathematical model based on mass and heat transfer for each greenhouse component has been modified to predict the inside climate conditions and calculate the water production of the system. The simulation is carried out for the hottest day of Borg Elarab, Egypt.

\section{SYSTEM DESCRIPTION}

Figure 1 clarifies the Conceptual Configuration of the on-roof transparent solar still coupled with agriculture greenhouse system. The system consists of a greenhouse cavity covered with transparent cover, a condenser at exit of greenhouse cavity, vertical and inclined risers, down comer channel, short chimney, a set of simple transparent solar still units placed in vertical and inclined risers.

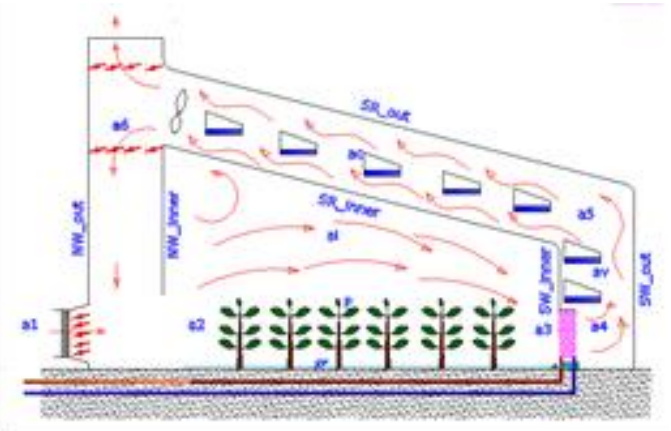

Fig .1. Conceptual Configuration of the GH Integrated With Roof Solar Stills

Figure 2 clarifies the Solar Still Configuration. A net of aluminum metal coated with black colour is placed on the base of the solar still units.

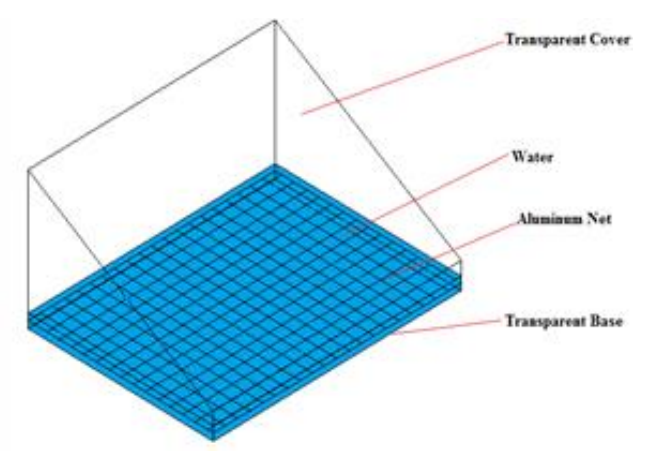

Fig .2. Conceptual Configuration of the Solar Still Unit

Part of the solar radiation is transmitted for plant photosynthesis process and the main part is absorbed by the solar still units for saline water desalination. The rest of solar energy is absorbed by transparent covers of the greenhouse and solar still units and get heated to enhance the air natural circulation. 
The circulating air (coming from the GH down comer channel) is mixed with fresh ambient air to adjust its temperature and relative humidity to be suitable with plant requirements, Figure (1). The mixed air passes through GH cavity and entrain the water vapor produced by plant inspiration. Then, part of this humid air passes through a chilled water condenser to condense as fresh water while the other part is bypassed. After that air is mixed and passes through vertical and inclined risers to cool the solar still units and get heated causing natural draft.

\section{MATHEMATICAL MODEL}

Mathematical model is developed to calculate the hourly transmitted and absorbed solar radiation for each GH surface based on clear sky day model [5] and quantify the $\mathrm{GH}$ performance based on mass and energy balance for each $\mathrm{GH}$ component where the following assumptions were taken in the consideration: a) uniform distribution for circulating air temperature and relative humidity; b) The temperature at deep ground is constant and evaporation from the greenhouse floor is negligible; c) lumped system is considered for each $\mathrm{GH}$ component; d) Thermal properties of the plants are same as those of water; f) One dimensional model.

\section{RESULTS AND DISCUSSIONS}

The thermal performance of the system is illustrated based on developed model calculations for environmental conditions of the hottest day (the 11th of July) which represents summer season of Borg Elarab, Egypt. Design and operational parameters that have been used as input parameters for the developed mathematical model are given in Table 1.
Table 1. Input parameters

\begin{tabular}{|c|c|c|c|}
\hline \multicolumn{2}{|c|}{ Geometrical parameters } & \multicolumn{2}{|c|}{ Operational parameters } \\
\hline$A_{g r}$ & $160 \mathrm{~m}^{2}$ & $m_{\text {air }}$ & $0.5 \mathrm{~kg} / \mathrm{s}$ \\
\hline$B_{c}$ & $1.5 \mathrm{~m}$ & $M_{p}$ & $1600 \mathrm{~kg}$ \\
\hline$N_{S S, r}$ & 60 & $\Delta T_{a p p}$ & $5^{\circ} \mathrm{C}$ \\
\hline$N_{S S, h}$ & 120 & $T_{c o}$ & $10^{\circ} \mathrm{C}$ \\
\hline$W$ & $20 \mathrm{~m}$ & \multicolumn{2}{|c|}{ Plant parameters } \\
\hline $\mathrm{L}$ & $8 \mathrm{~m}$ & $I_{p}$ & $0.03[6]$ \\
\hline$W_{b}$ & $1 \mathrm{~m}$ & $L A I$ & $3[6]$ \\
\hline$L_{b}$ & $0.75 \mathrm{~m}$ & \multirow{2}{*}{$r_{a}$} & \multirow{2}{*}{$\begin{array}{l}50 \text { (day) to } 5000 \\
\text { (night) } S / m[7]\end{array}$} \\
\hline$h_{w}$ & $0.01 \mathrm{~m}$ & & \\
\hline$\beta$ & $30^{\circ}$ & $r_{s}$ & $250 \mathrm{~S} / \mathrm{m}[7]$ \\
\hline$t_{n e t}$ & $0.005 \mathrm{~m}$ & & \\
\hline \multicolumn{4}{|c|}{ Thermal and optical parameters } \\
\hline$\alpha_{p}$ & $0.4 \quad[8]$ & $\rho_{w}$ & $1000 \mathrm{~kg} / \mathrm{m}^{3}$ \\
\hline$\alpha_{g}$ & $0.06[9]$ & $\rho_{A l}$ & $2712 \mathrm{~kg} / \mathrm{m} 3$ \\
\hline$\alpha_{g r}$ & $0.4[10]$ & $\tau_{g}$ & [12] \\
\hline$\alpha_{a l}$ & 0.92 & $\tau_{w}$ & 0.7 \\
\hline$\alpha_{w}$ & 0.89 & $C_{p, g}$ & $4190 \mathrm{~J} / \mathrm{kg} \mathrm{k}[11]$ \\
\hline$\varepsilon_{g}$ & 0.92 & $C_{p, p}$ & $4190 \mathrm{~J} / \mathrm{kg} \mathrm{k}[13]$ \\
\hline$\varepsilon_{g r}$ & 0.93 & $C_{p, a l}$ & 921.096 \\
\hline$\varepsilon_{p}$ & 0.92 & $H_{b}$ & $1 \mathrm{w} / \mathrm{m}^{2 o} \mathrm{C} \quad[14]$ \\
\hline$\varepsilon_{w}$ & 0.4733 & $T_{o}$ & $17^{\circ} \mathrm{C}$ \\
\hline$\rho_{g}$ & \multicolumn{3}{|c|}{$2500 \mathrm{~kg} / \mathrm{m}^{3}[11]$} \\
\hline
\end{tabular}

The ambient temperature and relative humidity is shown in Figure 3. The ambient temperature varies from 23.5 to $31 \mathrm{oC}$ and the ambient relative humidity varies from 55 to $91 \%$.

Figures 4 and 5 show the effect of using AL-metal with area ratio between the metal net and the base of $20 \%$ on the performance of climate inside the greenhouse. It is seen that changing the area ratio did not cause any change in the inside microclimate conditions.

Figure 6 and 7 show the effect of using AL-metal on the $\mathrm{GH}$ fresh water production and the transmitted solar radiation respectively.

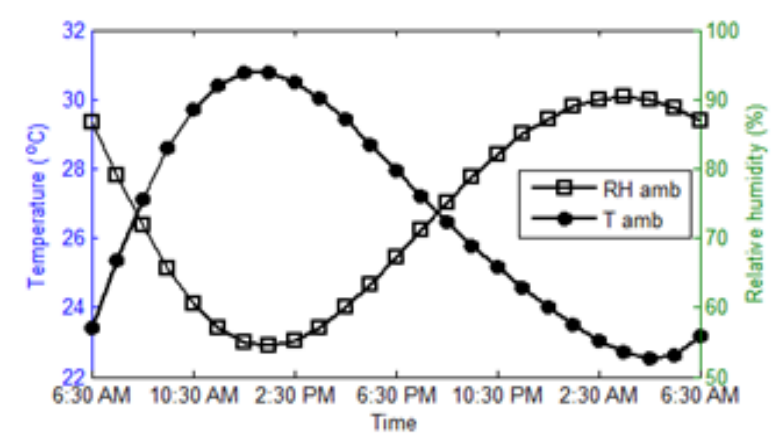

Fig .3. Ambient conditions (temperature and relative humidity) 


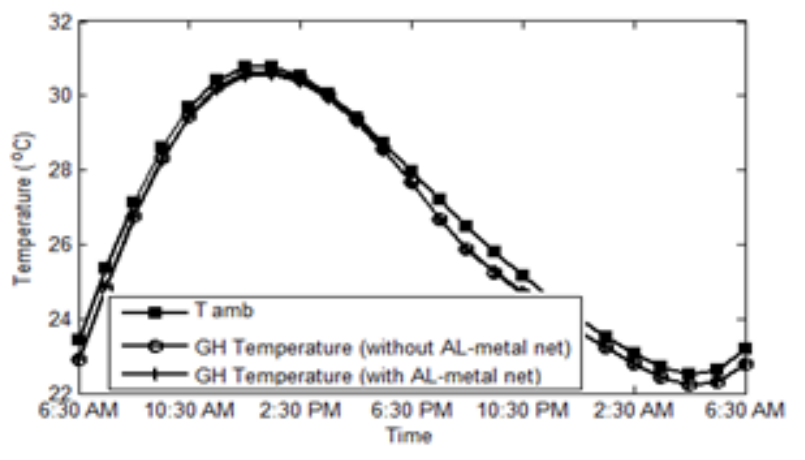

Fig .4. Effect of using AL-metal net on GH temperature.

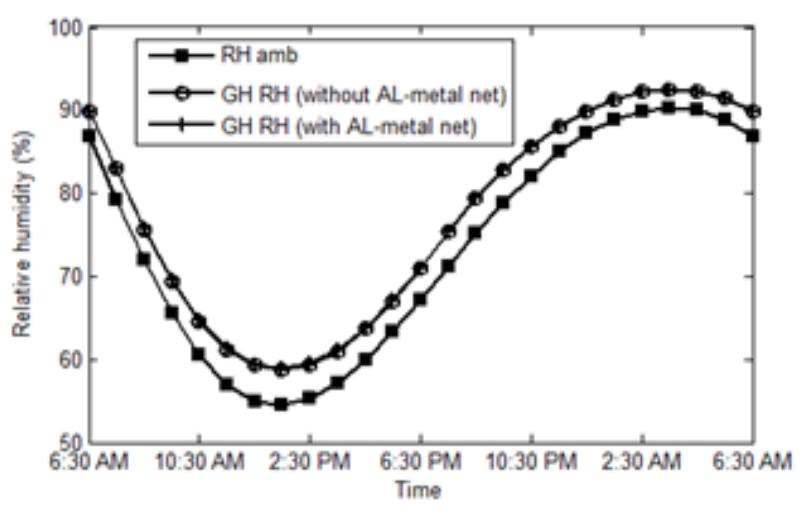

Fig .5. Effect of using AL-metal net on GH RH.

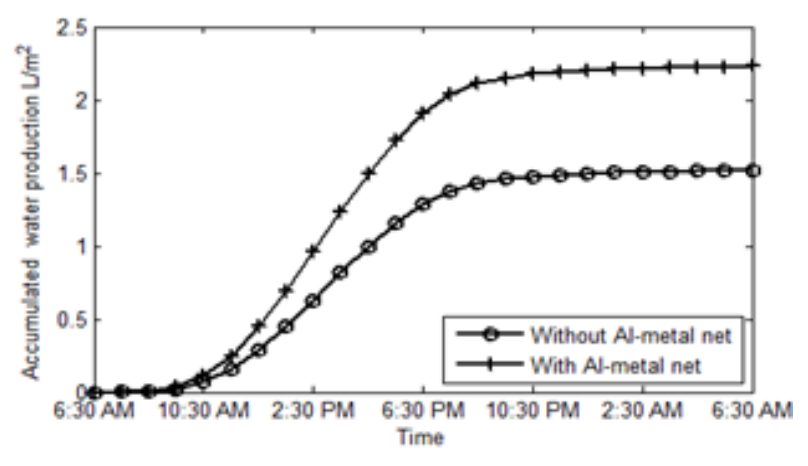

Fig .6. Effect of using AL-metal net on water production.

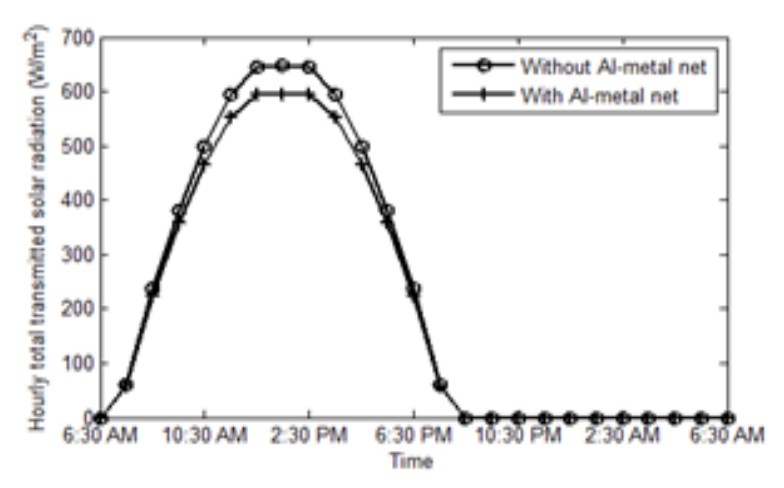

Fig .7. Effect of using AL-metal net on solar radiation transmittance.

\section{CONCLUSIONS}

It is concluded that the developed GH-Still integrated system can produce its needs of water for irrigation purposes. Using AL-metal net with area of $20 \%$ of the solar still base area increases the water production by $50 \%$. The transmitted solar radiation slightly affected by the metal net, but the internal performance of the greenhouse was not affected.

\section{ACKNOWLEDGMENT}

This research paper is supported through research project with title of "Solar-Greenhouse-Desalination System Self productive of Energy and Irrigating Water Demand". The project is funded by STDF (Science \& Technology Development Fund) with Project no. 10495, (2015-2016).

\section{REFERENCES}

[1] FAO2013,"Good Agricultural Practices for greenhouse vegetable crops: Principles for Mediterranean climate areas", ISBN 978-92-5107649-1, 2013.

[2] Gasser Hassan, Alaa Salah, Mohamed Elhelw, Amany Hassan and Hassan Fath,"Development of a Novel Solar Driven Agriculture Greenhouse: Self Sufficient of Energy and Irrigating Water", International Desalination Association (IDA) World Congress on Desalination and Water Reuse 2015/San Diego, CA, USA, REF: IDAWC15- Hassan, August (2015)

[3] Tesfaldet Yohannes and Hassan Fath, "Thermal Analysis of a Novel Agriculture Greenhouse: Self Sufficient of Energy and Irrigating Water", 24th Canadian Congress of Applied Mechanics, June 2-6 (2013).

[4] Radwan A. and Hassan Fath, "Thermal Performance of Greenhouse with Built-in Solar Distillation System: Experimental Study", Desalination, Vol. 181, 1-3, 5, 193-206 (2005).

[5] American Society of Heating Refrigeration and Air conditioning Engineers, "ASHRAE Handbook of Fundamentals," Atlanta, (1993).

[6] F. Berroug, E. Lakhal, M. El Omari, M. Faraji, and $\mathrm{H}$. El Qarnia, "Thermal performance of a 
greenhouse with a phase change material north wall," Energy and Buildings, vol. 43, pp. 30273035, 2011.

[7] M. Chaibi and T. Jilar, "System design, operation and performance of roofintegrated desalination in greenhouses," Solar energy, vol. 76, pp. 545561, 2004.

[8] V. Sethi, "On the selection of shape and orientation of a greenhouse: Thermal modeling and experimental validation," Solar Energy, vol. 83, pp. 21-38, 2009.

[9] P. Sharma, G. Tiwari, and V. Sorayan, "Temperature distribution in different zones of the micro-climate of a greenhouse: a dynamic model," Energy conversion and management, vol. 40, pp. 335-348, 1999.

[10] M. Ghosal and G. Tiwari, "Modeling and parametric studies for thermal performance of an earth to air heat exchanger integrated with a greenhouse," Energy conversion and management, vol. 47, pp. 1779-1798, 2006.

[11] F. P. Incropera, D. P. Dewitt, T. L. Bergman, and A. S. Lavine, Fundamentals of Heat and Mass Transfer, Sixth ed.: John Wiley \& Sons, Inc., 2007.

[12] M. Chaibi, "Analysis by simulation of a solar still integrated in a greenhouse roof," Desalination, vol. 128, pp. 123-138, 2000.

[13] R. Singh and G. Tiwari, "Thermal heating of controlled environment greenhouse: a transient analysis," Energy conversion and management, vol. 41, pp. 505-522, 2000.

[14] V. Sethi, "On the selection of shape and orientation of a greenhouse: Thermal modeling and experimental validation," Solar Energy, vol. 83, pp. 21-38, 2009. 